\title{
Voluntary affiliation to Peru's individual accounts pension system
}

\begin{abstract}
Carmen A. Li and Javier Olivera
Department of Economics, University of Essex, United Kingdom; Department of Economics, Catholic University of Leuven, Belgium

Abstract One important aspect in the design of social protection is coverage. In Peru, as in most Latin American countries, social security coverage is mandatory only for workers in the formal sector. This article investigates the determinants of voluntary affiliation to Peru's individual accounts pension system. It is found that married males with more than high-school level education living in high income households and with other family members already affiliated to the individual accounts pension system have a higher likelihood of voluntary affiliation. Although the results suggest that family-based safety nets might be substitutes for voluntary participation in the individual accounts pension system, nonetheless, extending pension coverage and addressing poverty remain as challenges for government involvement.
\end{abstract}

Keywords pension scheme, old age risk, scope of coverage, gaps in coverage, Peru

\section{Introduction}

Since Chile replaced its public pay-as-you-go (PAYG) pension system with a defined contribution, fully-funded and privately managed system based on individual accounts in 1981, many other Latin American countries have followed a similar

Address for correspondence: Carmen A. Li, Department of Economics, University of Essex, Wivenhoe Park, Colchester CO4 3SQ, United Kingdom; E-mail: carma@essex.ac.uk. Javier Olivera, Department of Economics, Catholic University of Leuven, Naamstraat 69, Leuven 3000, Belgium; E-mail: javier.olivera@ econ.kuleuven.be.

We are very grateful for the helpful suggestions of Roy Bailey, Chris Gerry, Tim Hatton, Erik Schokkaert and two anonymous referees. The usual disclaimer applies. 
reform path. It is argued that systems of individual accounts are more fiscally sustainable than PAYG systems and also contribute to the development of financial markets. However, after examining pension reforms in several Latin American countries, ${ }^{1}$ Gill, Packard and Yermo (2005) and Arenas de Mesa and Mesa-Lago (2006) identify some challenges related to their long-run sustainability and effectiveness: low and declining coverage rates, the high level of administrative costs, the uniformity of pension fund portfolios and the problem of establishing an efficient annuity market to provide adequate retirement pensions.

The problem of limited pension coverage $e^{2}$ is one of the main weaknesses of PAYG and individual accounts pension systems in Latin America. Table 1 shows that in 2007 and in relation to the economically active population (EAP), 64.2 per cent of the workforce was affiliated to an individual accounts private pension system but only 27.2 per cent contributed actively. ${ }^{3}$ Low coverage levels and the discrepancy between the total number of affiliates and the number who actually contribute to pension funds cast serious doubts about the adequacy of provisions for old age. Mesa-Lago (2004) argues that individual accounts private pension systems have been designed mainly for urban workers in the formal sector with stable jobs and earning above-average wages. Affiliation in the formal sector (i.e. the sector that complies with all or some of commercial and labour regulations) is mandatory. Therefore, the low percentages shown reflect the large informal sector (the unofficial sector beyond government regulation and taxation), for which affiliation to an individual accounts private pension system is voluntary. ${ }^{4}$

Affiliation - both, for workers with mandatory or voluntary coverage - does not necessarily imply contributing to the pension fund; affiliated workers might default on their pension contributions, might leave the labour market, or might change their sector of employment, etc. Poverty may also contribute to low levels of coverage because limited family resources must often be allocated to satisfy immediate needs, at the expense of possible longer-term needs.

This paper aims to examine what prompts Peruvians to contribute voluntarily to the private individual accounts pension system and, therefore, provide some

1. See also Rofman (2005), Jimenez and Cuadros (2003), Uthoff (2001), Schmidt-Hebbel (1999), Cruz-Saco and Mesa-Lago (1998), Queisser (1998) and Holzmann (1997), for an overview of the main advantages and disadvantages of the pension reform in Latin America.

2. Coverage is defined as the ratio of people insured (in any pension system) to population (or economically active population). This definition is simple to apply but overestimates coverage because workers can affiliate as participants but not make contributions. Rofman and Lucchetti (2006) discuss the problems of measuring coverage in Latin America and attempt to measure it.

3. Active contributors are defined as affiliates that contributed in the last month, with the exception of Mexico where it refers to the last six months.

4. See Jimenez and Cuadros (2003) for explanations linking low pension coverage and the informal sector. For all types of contributory pension system in Latin America, coverage for self-employed persons is voluntary in most countries, but mandatory in Argentina, Brazil, Costa Rica and Uruguay. 
Table 1. Private pension system coverage in Latin America: Affiliates and Contributors (December, per cent of $E A P^{\star}$ )

\begin{tabular}{|c|c|c|c|c|c|c|c|c|c|c|c|c|}
\hline \multirow[t]{2}{*}{ Country } & \multicolumn{2}{|l|}{2002} & \multicolumn{2}{|l|}{2003} & \multicolumn{2}{|l|}{2004} & \multicolumn{2}{|l|}{2005} & \multicolumn{2}{|l|}{2006} & \multicolumn{2}{|l|}{2007} \\
\hline & Aff. & Cont. & Aff. & Cont. & Aff. & Cont. & Aff. & Cont. & Aff. & Cont. & Aff. & Cont. \\
\hline Argentina & 54.9 & 18.2 & 56.0 & 19.7 & 58.3 & 20.6 & 60.8 & 24.5 & 64.0 & 25.8 & 60.3 & 24.5 \\
\hline Bolivia & 23.1 & 10.8 & 24.8 & 9.7 & 24.8 & 11.1 & 25.9 & 12.3 & 26.7 & 13.3 & 28.2 & 13.3 \\
\hline Chile & 111.8 & 57.0 & 113.9 & 59.1 & 111.4 & 56.2 & 116.5 & 59.6 & 112.6 & 58.0 & 113.6 & 61.2 \\
\hline Colombia & 23.6 & 11.2 & 25.2 & 12.3 & 28.5 & 11.1 & 30.4 & 11.7 & 35.1 & 14.8 & 38.0 & 17.1 \\
\hline Costa Rica & 63.1 & 47.5 & 64.9 & 47.4 & 72.0 & 49.1 & 75.2 & 49.1 & 79.2 & 52.0 & 81.6 & 55.8 \\
\hline El Salvador & 36.7 & 17.4 & 38.6 & 17.9 & 40.9 & 17.2 & 43.8 & 17.3 & 49.1 & 18.4 & 52.5 & 18.8 \\
\hline Mexico & 71.6 & 29.9 & 75.6 & 29.8 & 76.8 & 29.8 & 80.4 & 30.2 & 84.2 & 31.0 & 84.5 & 32.2 \\
\hline Peru & 27.2 & 10.7 & 28.2 & 11.8 & 29.1 & 11.6 & 30.3 & 11.0 & 31.5 & 11.0 & 32.5 & 13.4 \\
\hline $\begin{array}{l}\text { Dominican } \\
\text { Rep. }^{1}\end{array}$ & n.a. & n.a. & 22.3 & 14.6 & 27.7 & 14.8 & 32.4 & 15.3 & 36.0 & 18.9 & 40.2 & 20.8 \\
\hline Uruguay & 41.4 & 18.7 & 41.1 & 21.7 & 42.8 & 22.4 & 45.2 & 25.2 & 45.3 & 26.0 & 47.2 & 27.7 \\
\hline $\begin{array}{l}\text { Weighted } \\
\text { Total }\end{array}$ & 54.3 & 23.2 & 55.4 & 23.4 & 57.5 & 23.4 & 60.2 & 24.4 & 63.6 & 25.8 & 64.2 & 27.2 \\
\hline
\end{tabular}

* Economically Active Population

${ }^{1}$ In the Dominican Republic, the private pension pillar was implemented in 2003.

Source: AIOS (2007).

explanations for the low pension coverage rate. Peru reformed its pension system in 1993 and moved in the direction of private individual accounts. Unlike Chile, Peru has not dismantled the PAYG public pension system completely, which continues to operate in parallel. Affiliation to either the PAYG or the individual accounts pension system is mandatory for all formal salaried workers but voluntary for informal workers. Peru is an interesting case study because of its low pension coverage rate and large informal sector. The International Labour Organization (ILO) estimated that 55.0 per cent of the Peruvian urban labour force in 2007 was "informal" (ILO, 2008). ${ }^{5}$ As shown in Table 2, 32.5 per cent of the EAP was affiliated to the country's individual accounts pension system (SPP) but only 13.4 per cent were actively contributing to individual accounts.

Some previous studies (Cox and Edwards, 2002; Holzmann, Packard and Cuesta, 2000; Packard, Shinkai and Fuentes, 2002; and Barr and Packard, 2005) have tried to

5. The ILO definition of informal sector includes self-employed persons (excluding professionals and technicians), unpaid family workers, and employers and employees working in establishments with less than 6 persons engaged and domestic workers. 
Table 2. Social security participation in Peru (December, per cent)

\begin{tabular}{|c|c|c|c|c|c|c|c|}
\hline \multirow[t]{2}{*}{ Year } & \multicolumn{3}{|l|}{ SPP } & \multicolumn{2}{|l|}{ SNP } & \multicolumn{2}{|l|}{ Total } \\
\hline & Aff/EAP & Cont/EAP & Cont/Aff & Aff/EAP & Cont/EAP & Aff/EAP & Cont/EAP \\
\hline 1993 & 7.4 & n.a. & n.a. & n.a. & n.a. & n.a. & n.a. \\
\hline 1994 & 11.1 & n.a. & n.a. & n.a. & n.a. & n.a. & n.a. \\
\hline 1995 & 12.7 & n.a. & n.a. & n.a. & 6.8 & n.a. & n.a. \\
\hline 1996 & 16.9 & n.a. & n.a. & n.a. & 6.4 & n.a. & n.a. \\
\hline 1997 & 18.3 & n.a. & n.a. & n.a. & 6.9 & n.a. & n.a. \\
\hline 1998 & 20.1 & 9.2 & 45.6 & n.a. & 5.8 & n.a. & 15.0 \\
\hline 1999 & 22.1 & 10.5 & 45.7 & n.a. & 5.0 & n.a. & 15.5 \\
\hline 2000 & 23.8 & 9.9 & 41.7 & 7.7 & 4.2 & 31.5 & 14.1 \\
\hline 2001 & 25.5 & 10.1 & 41.4 & 7.9 & 4.0 & 33.4 & 14.1 \\
\hline 2002 & 27.2 & 10.7 & 39.4 & 8.3 & 4.1 & 35.5 & 14.8 \\
\hline 2003 & 28.2 & 11.8 & 41.9 & 8.6 & 4.1 & 36.8 & 15.9 \\
\hline 2004 & 29.1 & 11.6 & 39.9 & 9.0 & 4.1 & 38.1 & 15.7 \\
\hline 2005 & 30.3 & 11.0 & 36.2 & 9.6 & 4.2 & 39.9 & 15.2 \\
\hline 2006 & 31.5 & 11.0 & 34.8 & 10.8 & 4.6 & 42.3 & 15.6 \\
\hline 2007 & 32.5 & 13.4 & 41.4 & 12.3 & 5.3 & 44.8 & 18.7 \\
\hline
\end{tabular}

Notes: n.a. Not available. The army and police force have a separate social security system.

Sources: Superintendency of Banks and Insurance of Peru (Series históricas; Boletín informativo mensual);

Public Pension Standardization Office (Estadísticas ONP; 2000-2007), and AIOS (1999-2007).

uncover the determinants of affiliation to private pension systems in Latin American countries. They applied a binary choice model but without distinguishing between mandatory and voluntary affiliation. It is to be noted that in countries with a large number of informal workers, and for whom affiliation in pension schemes is voluntary, their tests can be interpreted as one of examining the determinants of participation in the formal sector rather than of pension system affiliation.

We consider that it is not adequate to include in the analysis individuals with mandatory coverage, because they do not have any choice. Hausman, Abrevaya and Scott-Morton (1998) showed that even a relatively small amount of misclassification can lead to significant bias in large samples. ${ }^{6}$ Moreover, empirical results quoted

6. Ordinary least squares (OLS) estimator is still appropriate when the measurement error in the dependent variable is uncorrelated with the explanatory variables. In contrast, measurement error in the binary limited dependent variable causes inconsistent estimates when traditional probit or logit techniques are applied. See Hausman (2001). 
without this distinction might not provide an accurate assessment of the possibility of extending pension system coverage.

We contribute to the existing research by using data from the 2001 Peruvian household survey (ENAHO 2001-IV) conducted by the Instituto Nacional de Estadística e Informática (INEI, 2001), which distinguishes between mandatory and voluntary affiliation. To our knowledge, this is the first article that examines the issue of voluntary pension affiliation to the private individual accounts pension system. We also test for the importance of the extended family and family-based safety nets. ${ }^{7}$ The extended family plays a prominent role in Peru and, as a result, informal family arrangements might help protect family members from social, economic and life-cycle risks, including income losses associated with ageing. Thus, informal family safety nets could act as substitutes for formal social security. Nevertheless, policy-makers are concerned about both the sustainability and effectiveness of informal social security measures in protecting older people from poverty (Holzmann, Packard and Cuesta, 2000). A better understanding of the affiliation motive might help to evaluate the coverage limits of the private individual accounts pension system, draw attention to the need to rebalance the different pension pillars, and design policies that could help to increase coverage, smooth consumption and alleviate poverty.

It would have been desirable to differentiate between workers who do - or do not - contribute to their pension funds, but most of the household surveys do not provide information related to contribution histories. The study by Barr and Packard (2005) is an exception. They used a specially-designed survey Encuesta Sobre Prevision de Riesgos Sociales (PRIESO) that asked 1,000 individuals in Lima, Peru, about their contributions to pension accounts - but did not ask if their affiliation was voluntary or mandatory.

Our results show that the profile of an individual who is likely to choose to affiliate voluntarily to the private individual accounts pension system is quite specific: only married males with more than high-school level education living in relatively high-income households and with other family members already affiliated to the individual accounts pension system. Informal family arrangements (e.g. money transfers and remittances) reduce the possibilities for the extension of pension system coverage. These findings complement those of Barr and Packard (2005) and Packard, Shinkai and Fuentes (2002) and lend support to the "low pension coverage, social exclusion, poverty" literature. Hence, they suggest a need to reassess the role of government in achieving poverty relief and income redistribution through consumption smoothing and old-age insurance.

7. These informal arrangements may be indirectly observed through family size, investments in children's education (Jellal and Wolff, 2002), informal old-age security provided by children (Hoddinott, 1992), help given by older people to their children in domestic tasks, risk-sharing agreements between family members (Kotlikoff and Spivak, 1981; Victorio, 2002), co-residence, etc. 
The paper is organised as follows. The next section briefly describes Peru's pension system and discusses some conventional arguments used to explain low coverage. We then present the theoretical framework, which incorporates insights from Kotlikoff and Spivak (1981) and Brown (2001). Following a discussion of the data and hypothesis, the econometric model is introduced and the empirical results analyzed. The final section presents conclusions.

\section{The private individual accounts pension system in Peru}

Since 1993 Peru has operated a parallel old-pension system, with the introduction of a privatized system of defined contribution individual accounts alongside the public PAYG defined-benefit system. Table 2 shows the coverage provided under the public defined-benefit system Sistema Nacional de Pensiones (SNP) or the Sistema Privado de Pensiones (SPP). In practice, the government has indirectly restricted access to coverage under the SNP. Workers affiliated to the public SNP system can choose to remain there or switch to the private system at any time. However, switching from the private SPP system to the public system is not allowed, unless there is proven illegal malpractice in the process of affiliation. Workers included on the payroll for the first time can choose between the SNP and the SPP, but if no decision is made within ten days of starting employment workers are automatically affiliated to the SPP. In addition, workers already covered by the SNP but who change jobs have to confirm that they wish to remain in the SNP, otherwise they are transferred automatically to the SPP. ${ }^{8}$

Affiliation to either pension system is mandatory only for formal salaried workers. The remaining workers for whom affiliation is voluntary are very heterogeneous and we label them informal workers (self employed, family workers, employees of micro enterprises, etc.).

As explained, new formal salaried workers can choose to join either pension system; but informal workers have to decide, first, whether to seek coverage, or not, under either of the pension systems and, second, to choose between the public and private system. Unfortunately, household survey data does not provide information on how many informal workers choose to affiliate to the SNP. In any case, Figure 1 shows that voluntary coverage in the SNP is very low compared with that in the SPP. In 2002, the flow of monthly voluntary affiliation to the SPP was almost seven times higher than in the SNP, but this gap decreased significantly in the two years that followed before increasing steeply again in 2006. The gap was practically closed in 2007. These fluctuations and surges were prompted by policies implemented by the private individual accounts administrators (Administradoras de Fondos de Pensiones - AFPs) to attract new customers as well as changes in regulations that made the SPP more competitive.

8. The army and police force have a separate social security system. 
Figure 1. Voluntary enrolment in Peru's private (SSP) and public (SNP) pension systems

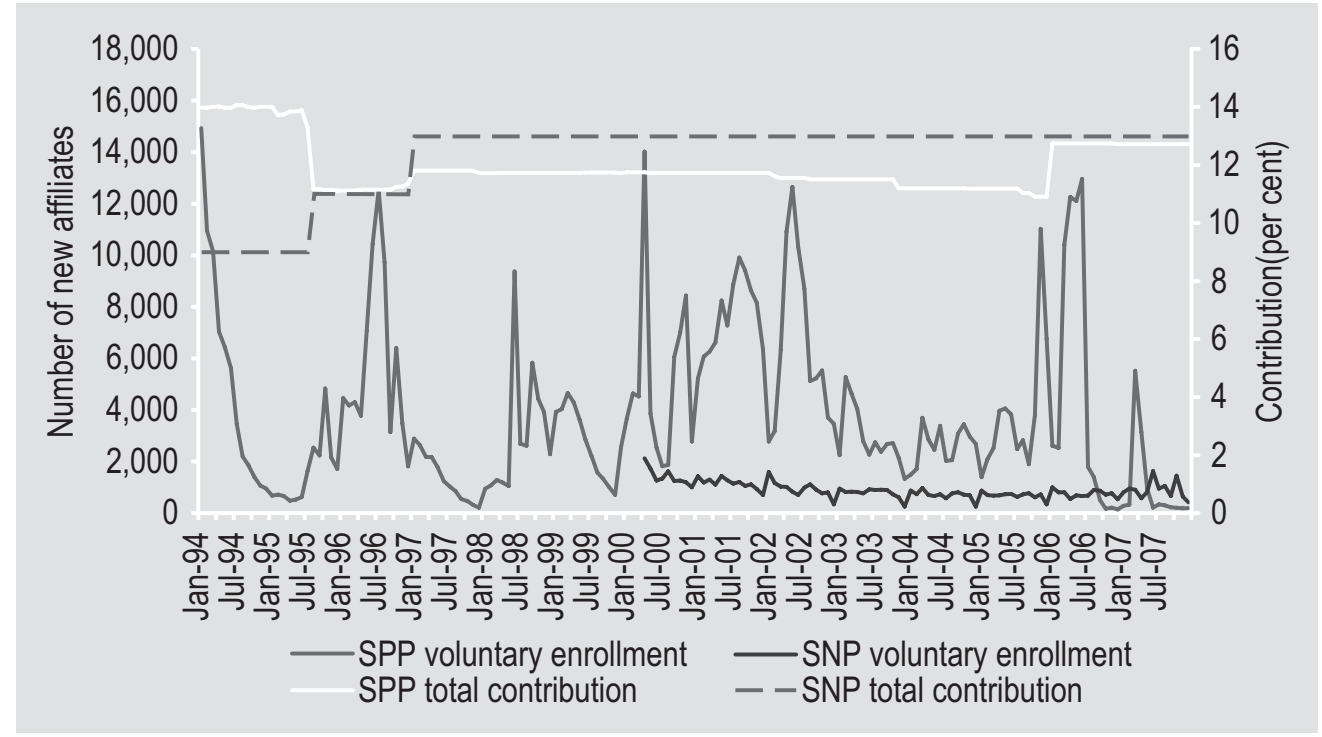

Note: Data for workers voluntary enrolled in the SNP (available only from June 2000) are potentially overestimated because these include individuals who previously were compulsory enrolled in the SNP.

Source: Superintendency of Banks and Insurance of Peru (Series históricas; Boletín informativo mensual); Public Pension Standardization Office (Estadísticas ONP).

The SPP system is relatively simple since workers cannot affiliate to more than one AFP at a time and contributions equate to a fixed percentage of their monthly earnings during their working lives. Unless the individual retires earlier, these funds are accumulated in an individual account until the individual reaches the retirement age (age 65 for men and women). At retirement, the accumulated balance remains in the AFP or is transferred to an insurance company that converts the sum to a monthly pension based on life expectancy. There are three main types of old-age benefits: programmed withdrawal managed by the AFP, immediate life annuities managed by insurance companies (the pensioner uses the balance to purchase an annuity from an insurance company), and a mixture of programmed withdrawals and an annuity. In contrast to the Chilean system, Peru's SPP does not include a guaranteed minimum pension. ${ }^{9}$

In addition to contributing to old-age pension benefits, worker's covered by the SPP also contribute separately to the cost of insurance covering disability and death

9. Until March 2007, a top-up amount was payable at the legal retirement age only to individuals born before 1946 with at least twenty years of contributions paid on earnings at least equal to the minimum wage, in order to raise their pension to a guaranteed minimum. Since then, the date of birth qualifying condition has been removed, but entitlement to the top-up amount is restricted to individuals who have switched from the SNP to the SPP. 
before retirement. Disability and survivor benefits are payable only if contributions were paid in four of the last eight months before the date of the onset of disability or death. Also, if the pensioner dies, then his or her dependants inherit a share of the old-age pension.

Each affiliated worker contributes 10 per cent of his or her monthly earnings to the pension fund, pays net commission fees equal to 1.81 per cent of monthly earnings and an average insurance (disability and sudden death) fee equal to 0.91 per cent of monthly earnings. Although the total commission fee of Peru's AFPs has been declining over the years, it is still one of the highest among the private pension systems in Latin America. ${ }^{10}$ The AFP invests individual pension contributions in the domestic and foreign capital markets and the government, through the Superintendent of Banks, Insurance and AFPs (Superintendencia de Banca y Seguros), supervises their performance.

As a percentage of the EAP, the number of individuals covered by the SPP in Peru is low. Moreover, in 2007, out of the 4.1 million individuals affiliated, only 1.7 million were actively contributing to an individual account. These figures represented 32.5 per cent and 13.4 per cent of the EAP, respectively. In turn, according to available data, the effective coverage rate (i.e. the percentage of affiliates to the SPP that actively contribute) has never been higher than 45.7 per cent (in 1998). Reaching a low of 36.2 per cent in 2005, the most recent figure from 2007 was 41.4 per cent (see Table 2).

Next we discuss the soundness of three popular arguments that are frequently used to explain why the SPP has failed to extend coverage to a larger segment of Peruvian society.

Argument 1: SPP contributions (plus commissions) are high relative to those for the SNP. In 1994, the contribution rate to the SNP was 9 per cent of monthly earnings ( 6 per cent from the insured worker and 3 per cent from the employer), whilst for the SPP the contribution rate paid by the affiliate was 10 per cent of monthly earnings plus an additional 4 per cent, which included administrative charges and insurance fees. In July 1995, the SNP contribution rate was increased to 11 per cent of monthly earnings (and was now borne only by the insured worker) whilst the SPP contribution rate decreased to 8 per cent of monthly earnings; but once the administrative and insurance fees are considered, the total contribution to the SPP was of a similar magnitude to that of the SNP. Also the retirement age was uniform for both systems; age 65 (men and women). ${ }^{11}$ In January 1997, the SNP contribution rate was increased to 13 per cent of monthly earnings. The "price" gap between both systems in terms of the total contribution rate narrowed to a mere 0.28 per cent of monthly earnings at the end of 2006. Figure 1 shows that, for individuals voluntarily affiliated, member-

10. See AIOS (2007).

11. Before 1995, under the SNP the retirement age was age 55 (women) or age 60 (men).

International Social Security Review, Vol. 62, 3/2009 @ 2009 The author(s) Journal compilation @ 2009 International Social Security Association 
ship of the SPP is associated with "prices" only up to mid-1996. During the period 1997-2007, when the "price" of belonging to the SPP became less than the SNP, the correlation is almost non-existent. The peaks of September 1998, April 1999 and April 2000 are related to the (temporal) AFP policy of affiliating university students irrespective of their work status. In sum, therefore, "prices" appear not to be associated with the choice of affiliation to the SPP. Moreover, it is interesting to note that according to PRIESO, the main reason why 22 per cent of individuals who switched from the SNP to the SPP, and 33 per cent of new members chose the SPP instead of the SNP, was "my employer forced me to change plans".

Argument 2: The expected retirement pension under the SPP is higher than the SNP but lower than the return from other forms of savings. The expected retirement pension, of course, depends mainly on lifetime income, life expectancy and investment returns. ${ }^{12}$ Most informal workers have low income, temporary jobs and, therefore, might not be able to accumulate enough in an individual account to finance an adequate retirement pension. However, if the argument holds, we should observe switches from the SNP to the SPP among prime-age workers with higher income. Unfortunately there is no available data to test this, but according to ENAHO 2006-IV, the average age of individuals affiliated in the SPP is 12 years younger than that for the SNP.

With regard to other forms of savings, Morón and Carranza (2003) estimate that the accrued returns from the stock market and deposits in both domestic and foreign currency are lower than individual account pension fund returns. Also, Carpio (2007) shows that pension savings partially crowd out Peruvian household savings. At present, there is an absence of research findings on how pension savings affect the accumulation of other household assets (e.g. real estate).

Argument 3: A lack of knowledge about pension systems and the perception that the SNP is better and more trustworthy than the SPP. Data from PRIESO reveals that, for 29 per cent of the sample, the most important reason for individuals not joining any pension system is "did not know, did not have enough information". In turn, 49 per cent of the interviewees who chose the SNP instead of the SPP did so because they perceived that "the State-administered scheme is better than the AFPs", the "ONP (Oficina de Normalización Previsional) [the public body that administers the PAYG system] will never disappear, whereas AFPs can go bankrupt" and the "AFPs plans have a bad reputation". Therefore, individual knowledge and

12. The current global financial and economic crisis is having a severe impact on capital returns and the performance of pension funds. Indeed, these adverse effects contributed in late-2008 to the Argentinean government integrating the private system of Administradora de Fondos de Jubilaciones y Pensiones (AFJP) into the country's PAYG pension system (SIPA — Sistema Integrado Previsional Argentino). 
institutional reputation do appear to matter in the decision to affiliate and in the choice of pension system.

\section{The theoretical framework}

The decision to affiliate in a pension system can be thought of as one where the individual must decide whether or not to purchase an insurance against the risk of loss of income during old age. One simple way of analysing this decision is to adapt the theoretical models of Kotlikoff and Spivak (1981) and Brown (2001) by including some features of Peru's private individual accounts pension system and, analogous to the equivalent variation in welfare analysis, compare the lifetime utility derived from consumption of an individual with and without affiliation to a pension system. ${ }^{13}$

In this setting, when both the administrative fee paid to the AFP and the contribution rate (a share of the monthly salary) are zero and also when the estimated probability of survival by the individual and the insurance company are equal, then we have the case of a "fair" annuity market where the "cost" of the annuity is zero. If this is the case, the (discounted) probability of survival could be interpreted as the price of future consumption and the individual will always prefer to affiliate because future consumption with affiliation is equivalent to the case of non-affiliation but with lower prices. This is the so-called "annuity puzzle", but there are several factors that can decrease the value of annuities such as administrative costs, divergence in the perceptions of the population and insurance companies concerning survival probabilities, different degrees of risk aversion, informal family safety nets that might substitute for formal social security, etc.

Indeed, within this framework, and as expected, it is possible to show that the gains from affiliation will be lower the lower the risk aversion; the higher the pension administrative fees; the higher the individual's time preference rate; ${ }^{14}$ and the larger the gap between the survival probability estimated by the individual and the insurance company, because individuals will not live long enough to receive the full benefits of the pension. Note that poor people tend to have a low survival rate and therefore they will have little incentive to participate in the individual accounts pension system.

Inter-family transfers, that are common practice in extended families but only implicitly captured in our basic framework, may reflect incomplete annuity markets

13. For simplicity, we assume no bequests, no other form of savings except the old-age pension, a separable consumption function, a constant stream of income over time and a constant relative risk aversion utility function.

14. This rate is very high, as in the case of poor people. Packard, Shinkai and Fuentes (2002) argue that, especially for the poor and self-employed, the decision not to affiliate can be a rational choice because it may limit their capacity to smooth consumption. 
(or more generally, imperfections in the capital market) and hence affect the decision to take up a pension. These family arrangements are part of a more general form of allocations over generations and are associated with forms of exchange within the family. ${ }^{15}$ Parents take care of children (education, food, clothes, etc.) while they are middle-aged. As the parents increase in age, they receive financial or in-kind support from their children as a form of exchange or compensation. Lucas and Stark (1985), Cox and Rank (1992) and Victorio (2002) analyse the patterns of intergenerational transfers and uncover empirical evidence suggesting that relations of exchange link generations within the family. In particular, Cox, Eser and Jimenez (1998) find that Peruvian family members expecting to receive social security transfers (i.e. pension and health care benefits) have a weaker incentive to enter into intergenerational arrangements for the purpose of old-age support. That is, their evidence suggests a negative correlation between the existence of informal agreements for old-age support and the probability of participating in a pension system.

In contrast to a formal social security institution where the payment of pensions can be legally enforced, informal family arrangements are not enforceable and require self-enforcement mechanisms. For example, Cigno (2000) mentions a set of basic principles called "family constitution". Other researchers, for instance Cox, Eser and Jimenez (1998) argue that family altruism, loyalty and trust are key to the enforcement of family arrangements. In fact, the risk of exclusion from the family network, as well as liquidity restrictions and limited access to the credit market, provide incentives to family members to fulfil agreements.

As a result of better information and trust within the family, family risk-sharing agreements have lower levels of transaction costs, moral hazard, adverse selection and deception than those found in conventional insurance markets (Kotlikoff and Spivak, 1981). Packard, Shinkai and Fuentes (2002) point out that informal social security arrangements might be superior to a pension system because the former covers a broader range of risks and is more flexible, so it could be tailored according to the needs of the individual. Recently, Li and Gerry (2009) have also emphasised how informal safety nets (i.e. support from relatives/friends and home production) helped the most vulnerable during the 1998 Russian crisis.

\section{Data, hypothesis, and explanatory variables}

We use data from ENAHO during the fourth quarter of 2001. This survey has been conducted yearly every quarter since 1995 and contains socio-economic information pertaining to households and their members. The sample size consists of 16,515 households including 76,635 individuals and it is representative at the national, urban and rural levels.

15. See Arrondel and Masson (2006), Laferrere and Wolff (2006), and Stark (1995) for a more comprehensive discussion on transfer motives and their implications.

๑ 2009 The author(s) Journal compilation @ 2009 International Social Security Association International Social Security Review, Vol. 62, 3/2009 
We drop all individuals with mandatory affiliation in the individual accounts pension system. Furthermore, we only include individuals belonging to the economically active population and exclude those belonging to extremely poor households. ${ }^{16}$ The final sample size is 22,221. Our unit of analysis is the individual and we account for individuals belonging to the same household by clustering.

There are two main characteristics of our sample that must be kept in mind. The first is related to the definition of our dependent variable. We exclude individuals with mandatory affiliation to the individual accounts pension system. The ENAHO 2001-IV specifically asks if the individual belongs to the individual accounts pension system (SPP), but does not directly ask if he or she belongs to the public PAYG pension system (SNP). There are only two pension systems in Peru so we can indirectly infer if a person belongs to the SNP: a person not participating in the SPP but paying monthly pension contributions is classified as one belonging to the SNP and is excluded from the sample.

The second characteristic is related to the effects of occupations on the probability of participation in the individual accounts pension system. An individual might change occupations over his or her working life. Therefore, it might not be true that an individual who is affiliated and who currently holds an "informal" occupation (e.g. self-employed) originally chose to affiliate on a voluntary basis. For instance, a self-employed individual who participates in the pension system at the time of the survey could have affiliated during his or her previous job when he or she was a "formal" worker. ${ }^{17}$ Unaccounted changes from formal to informal jobs (and vice versa) might introduce biases in the analysis. We decide not to use occupations as predictors for the probability of affiliation because of the mismatch between actual occupation and the timing of affiliation. For similar reasons and given the lack of data to disentangle chronic from temporary unemployment, we did not include "unemployed" as a regressor. Instead, we rely on the characteristics of the individual (age, gender, marital status, and education) to indirectly control for the employment/occupation status.

We are interested in examining how both personal and family characteristics as well as the existence of family-based arrangements affect the probability of affiliation to the individual accounts pension system. In view of our theoretical framework and data availability, we formulate the following hypotheses:

16. The Instituto Nacional de Estadística e Informática (INEI) classifies Peruvian households into extreme poor, poor and non-poor according to poverty lines based on expenditure thresholds: minimum food calorie intake for the case of extreme poverty and minimum goods and services for the case of poverty. We have also performed the regression including the extreme poor, which is available upon request. The results did not change qualitatively and given that the choice of affiliating for the extreme poor is not deemed a realistic one, we decided to present only the results excluding them.

17. According to ENAHO 2001-IV, 77 per cent of self-employed workers first affiliated to the SPP when they were "formal" workers. 
Hypothesis 1. Age has a positive and non-linear effect on the probability of voluntary SPP affiliation.

We expect a positive effect of age on affiliation. However, since the pension in the SPP depends directly on the length of the period in which contributions are made, it is possible that older workers might not have an incentive to affiliate to the SPP because they will not have sufficient time to accumulate funds to finance an adequate pension. Therefore, we expect a non-linear relation between age and affiliation.

Hypothesis 2. Individuals with more investment in human capital and belonging to households with higher income per capita have a higher probability of voluntary SPP affiliation.

We expect that more educated individuals living in households with higher per capita income will have a higher probability of affiliation because they would be better able to smooth consumption and allocate resources for social security.

We include variables to signal different education levels (postgraduate, undergraduate, vocational, high school and less than high school education). We also include income-related proxies such as household income per capita and a variable indicating whether any member of the household has liquid assets.

Hypothesis 3. The existence of an extended family and a large nuclear family with a high proportion of young and old members reduces the likelihood of voluntary SPP affiliation.

The effects of informal arrangements for old-age security on the probability of affiliation can be indirectly examined by using the number of household members, the proportion of children (younger than age 14) and older people (aged 65 or older) in the household, and the existence of an extended family.

Hypothesis 4. Family transfers decrease the likelihood of voluntary SPP affiliation.

As explained in the previous section, there are several reasons why family transfers might occur. One motive might be reciprocal "exchange" i.e. a family gives something because they expect to receive something in return. ${ }^{18}$ Intergenerational transfers evidence that families engage in informal social security arrangements, with children giving transfers to parents and vice versa. Therefore the existence of these arrangements in the family may reduce the probability of voluntary affiliation.

Unfortunately we do not have data on intergenerational transfers. Rather than parent-children transfers, we use a proxy to measure the effect of transfers on the probability of voluntary affiliation. Our data includes information on the provision

18. See Cox, Eser and Jimenez (1998) and Bhaumik and Nugent (2000) for an interesting analysis of Peruvian family exchange relations.

๑ 2009 The author(s) Journal compilation @ 2009 International Social Security Association International Social Security Review, Vol. 62, 3/2009 
and receipt of family transfers from and to other family members living outside the household. Therefore, our results should be treated with some caution. We expect that belonging to a household that receives or gives these transfers reduces an individual's likelihood of voluntary SPP affiliation.

We also include dummy variables for gender, marital status, head of household and holding private health insurance. These covariates are included to control for risk perception and women's expected value of the future pension, which depends on their own accumulated funds (working women are typically less well paid than men and are more likely to have interrupted careers) and the survivor benefits for married women. We also add controls to signal if the household is above the poverty level, if it is located in an urban or rural area, if other members of the household are affiliated to the SPP, if there are pensioners in the household, and if any household member has a life insurance. Tables 3 and 4 present the definition and descriptive statistics of the variables used in this study. We compare the means of our variables and find that all of the means between the voluntary affiliated and non-affiliated groups are statistically different except for the means of extended family and head ${ }^{\star}$ female.

The econometric model and the empirical results

We do not apply a standard probit model to determine the variables that correlate with the probability that an individual voluntarily affiliates to the SPP. Recall that we are excluding all individuals with mandatory coverage (either under the SNP or SPP) from the sample; hence the sample is not random. Ignoring this selectivity problem may lead to bias estimates and unreliable policy recommendations. Therefore, we apply a two-stage discrete choice version of Heckman (1979) to correct for selection bias. In this case, the dependent variable of the selection equation indicates if the individual's affiliation was mandatory (SPP or SNP) or not $\left(\mathrm{y}_{1}=1\right)$ while the outcome variable measures whether the individual participates voluntarily $\left(\mathrm{y}_{2}=1\right)$ or not in the SPP:

$$
\begin{aligned}
& y_{1}=1 \quad \text { if } \quad x_{1}^{\prime} \beta_{1}+\varepsilon_{1}>0 \\
& y_{2}=1 \quad \text { if } \quad x_{2}^{\prime} \beta_{2}+\varepsilon_{2}>0 \text { given that } y_{1}=1 \\
& y_{2}=0, \text { otherwise }
\end{aligned}
$$

To estimate this model we a) assume that the errors $\varepsilon_{1}$ and $\varepsilon_{2}$ have a bivariate normal distribution and that the explanatory variables are exogenously determined, and b) need at least one instrument that affects the selection equation but not the probability of voluntarily participating in the SPP. The chosen variable that fulfils those requirements is "informal", which takes the value of 1 if in the last week previous to the interview the person was self-employed, worked in a firm of less 
Table 3. Definition of variables

\begin{tabular}{|c|c|}
\hline Variable & Definition \\
\hline \multicolumn{2}{|l|}{ Individual characteristics } \\
\hline Age & Age in years \\
\hline Woman & Female $=1,0$ otherwise \\
\hline Married & Married $=1,0$ otherwise \\
\hline Married*Woman & Female and married $=1,0$ otherwise \\
\hline Head & Head of household $=1,0$ otherwise \\
\hline Head*Female & Head of household and female $=1,0$ otherwise \\
\hline Postgraduate & Postgraduate education $=1,0$ otherwise \\
\hline University & University education $=1,0$ otherwise \\
\hline Vocational and technical & Technical or vocational education $=1,0$ otherwise \\
\hline High School & Secondary education $=1,0$ otherwise \\
\hline Private health insurance & Individual holds a private health insurance $=1,0$ otherwise \\
\hline \multicolumn{2}{|l|}{ Household characteristics } \\
\hline HH income per capita & Natural logarithm income per capita of the household \\
\hline Liquid asset gains & $\begin{array}{l}\text { Liquid asset gains are interests from deposits and loans, dividends from shares } \\
\text { and equities and firm profits received in the last year by any member of the } \\
\text { household. Any member of household receiving liquid asset gains }=1,0 \text { otherwise }\end{array}$ \\
\hline $\mathrm{HH}$ is non poor & Household non poor $=1,0$ otherwise \\
\hline Urban & Household located in urban area $=1,0$ otherwise \\
\hline Household size & Number of members in the household \\
\hline Young dependants & Proportion of $\mathrm{HH}$ members younger than age 14 \\
\hline Old dependants & Proportion of $\mathrm{HH}$ members older than age 65 \\
\hline Extended family & Any relative in household but not nuclear family $=1,0$ otherwise \\
\hline Receiving family transfers & $\begin{array}{l}\text { Transfers and remittances from relatives in other households and received by } \\
\text { any member of the household during the last } 6 \text { months. Receiving transfers }=1,0 \\
\text { otherwise }\end{array}$ \\
\hline Providing family transfers & $\begin{array}{l}\text { Transfers and remittances provided by any member of the household to relatives } \\
\text { living in other households during the last } 3 \text { months. Providing transfers }=1,0 \\
\text { otherwise }\end{array}$ \\
\hline Other members in the SPP & $\begin{array}{l}\text { Other member of the household (except the interviewee) enrolled in the SPP }=1,0 \\
\text { otherwise }\end{array}$ \\
\hline Receiving pensions & $\begin{array}{l}\text { Any member of the household receiving a pension during the last six months }=1,0 \\
\text { otherwise }\end{array}$ \\
\hline Holding a life insurance & $\begin{array}{l}\text { Any member of the household paying life insurance during the last } 3 \text { months }=1,0 \\
\text { otherwise }\end{array}$ \\
\hline
\end{tabular}


Table 3. Continued

\begin{tabular}{ll}
\hline Variable & Definition \\
\hline Instruments & \\
\hline Informal & $\begin{array}{l}\text { Takes the value of } 1 \text { if the last week previous to the interview the person was self-employed, } \\
\text { worked in a firm of less than five workers or was unemployed but his/her last job was as a } \\
\text { self-employed person or in a firm with less than five, } 0 \text { otherwise }\end{array}$ \\
\hline Lost job & Any member of the household has lost his/her job during the last year $=1,0$ otherwise \\
\hline IIIness & $\begin{array}{l}\text { Any member of the household has been affected by a severe illness or accident during the } \\
\text { last year }=1 \text { and } 0 \text { otherwise }\end{array}$ \\
\hline Savings & $\begin{array}{l}\text { The person is able to save in the current economic situation of the household }=1,0 \\
\text { otherwise }\end{array}$ \\
\hline HH improvement & $\begin{array}{l}\text { The person has perceived an improvement in the living standard of the household with } \\
\text { respect to the last year }=1,0 \text { otherwise }\end{array}$ \\
\hline
\end{tabular}

than five employees, or was unemployed but his or her last job was in selfemployment or in a firm with less than five employees; and 0 otherwise.

Note that some of the control variables included in the model might be potentially endogenous. In particular, holding private health insurance and receiving and or providing family transfers might be endogenous (see Cox, Eser and Jimenez, 1998). The quality of service provided by Peru's public health system is deemed inadequate, so it is plausible to assume that the decision to affiliate with the SPP is subsequent to that of subscribing to a private health insurance scheme. For receiving and providing transfers we applied the exogeneity test suggested by Rivers and Vuong (1988). According to Wooldridge (2002), this approach can be applied to non-linear models with binary endogenous variables and has the advantage of being simple to compute.

To implement this procedure, we regress a linear probability model of the suspected endogenous variable on all the original variables of the model and the instruments (which are assumed to be correlated with the suspected endogenous variable but not with the dependent variable of the original equation) and obtained the predicted residuals. We also implement a Wald test for the significance of the predicted residuals. Then, we return to our original model, add this predicted residual together with all the variables of the model and test the null hypothesis that the predicted residuals are equal to zero i.e. the suspected variable is not endogenous.

The instruments chosen for the variable "receiving family transfers" are "lost job" (which takes the value of 1 if any member of the household has lost his or her job during the last year; and 0 otherwise) and "illness" (which takes the value of 1 if any member of the household has been affected by a severe illness or accident during the last year, and 0 otherwise). For the variable "providing family transfers", we use "savings"; (which takes the value of 1 if the individual is able to save in the current 
Table 4. Descriptive statistics

\begin{tabular}{|c|c|c|c|c|}
\hline \multirow[t]{2}{*}{ Variable } & \multicolumn{2}{|c|}{ Voluntarily affiliated } & \multicolumn{2}{|c|}{ Non-affiliated } \\
\hline & Mean & S.D. & Mean & S.D. \\
\hline \multicolumn{5}{|l|}{ Individual characteristics } \\
\hline Age & 41.1 & 13.3 & 36.7 & 15.8 \\
\hline Age squared & $1,862.5$ & $1,199.1$ & $1,597.8$ & $1,358.9$ \\
\hline Gender & 0.347 & 0.477 & 0.461 & 0.499 \\
\hline Marital status & 0.684 & 0.466 & 0.555 & 0.497 \\
\hline Head & 0.542 & 0.499 & 0.382 & 0.486 \\
\hline Head*Female & 0.063 & 0.242 & 0.072 & 0.258 \\
\hline Private health insurance & 0.066 & 0.249 & 0.011 & 0.102 \\
\hline Postgraduate & 0.024 & 0.154 & 0.001 & 0.037 \\
\hline University & 0.330 & 0.471 & 0.065 & 0.246 \\
\hline Vocational and technical & 0.205 & 0.404 & 0.088 & 0.283 \\
\hline High School & 0.281 & 0.450 & 0.453 & 0.498 \\
\hline \multicolumn{5}{|l|}{ Household characteristics } \\
\hline$\underline{\mathrm{HH}}$ income per capita & 7.254 & 0.765 & 6.585 & 0.735 \\
\hline$\underline{\mathrm{HH}}$ income per capita squared & 53.207 & 11.396 & 43.896 & 9.927 \\
\hline Liquid asset gains & 0.125 & 0.331 & 0.029 & 0.168 \\
\hline $\mathrm{HH}$ is non poor & 0.868 & 0.339 & 0.592 & 0.491 \\
\hline Urban & 0.885 & 0.319 & 0.687 & 0.464 \\
\hline Household size & 4.729 & 1.957 & 5.106 & 2.422 \\
\hline Young dependants & 0.218 & 0.198 & 0.234 & 0.203 \\
\hline Old dependants & 0.075 & 0.164 & 0.073 & 0.187 \\
\hline Extended family & 0.413 & 0.493 & 0.400 & 0.490 \\
\hline Receiving family transfers & 0.281 & 0.450 & 0.380 & 0.485 \\
\hline Providing family transfers & 0.299 & 0.458 & 0.215 & 0.411 \\
\hline Other members in the SSP & 0.438 & 0.497 & 0.177 & 0.382 \\
\hline Receiving pensions & 0.063 & 0.242 & 0.013 & 0.111 \\
\hline Holding a life insurance & 0.135 & 0.343 & 0.027 & 0.163 \\
\hline
\end{tabular}


Table 5. Rivers-Vuong endogeneity test

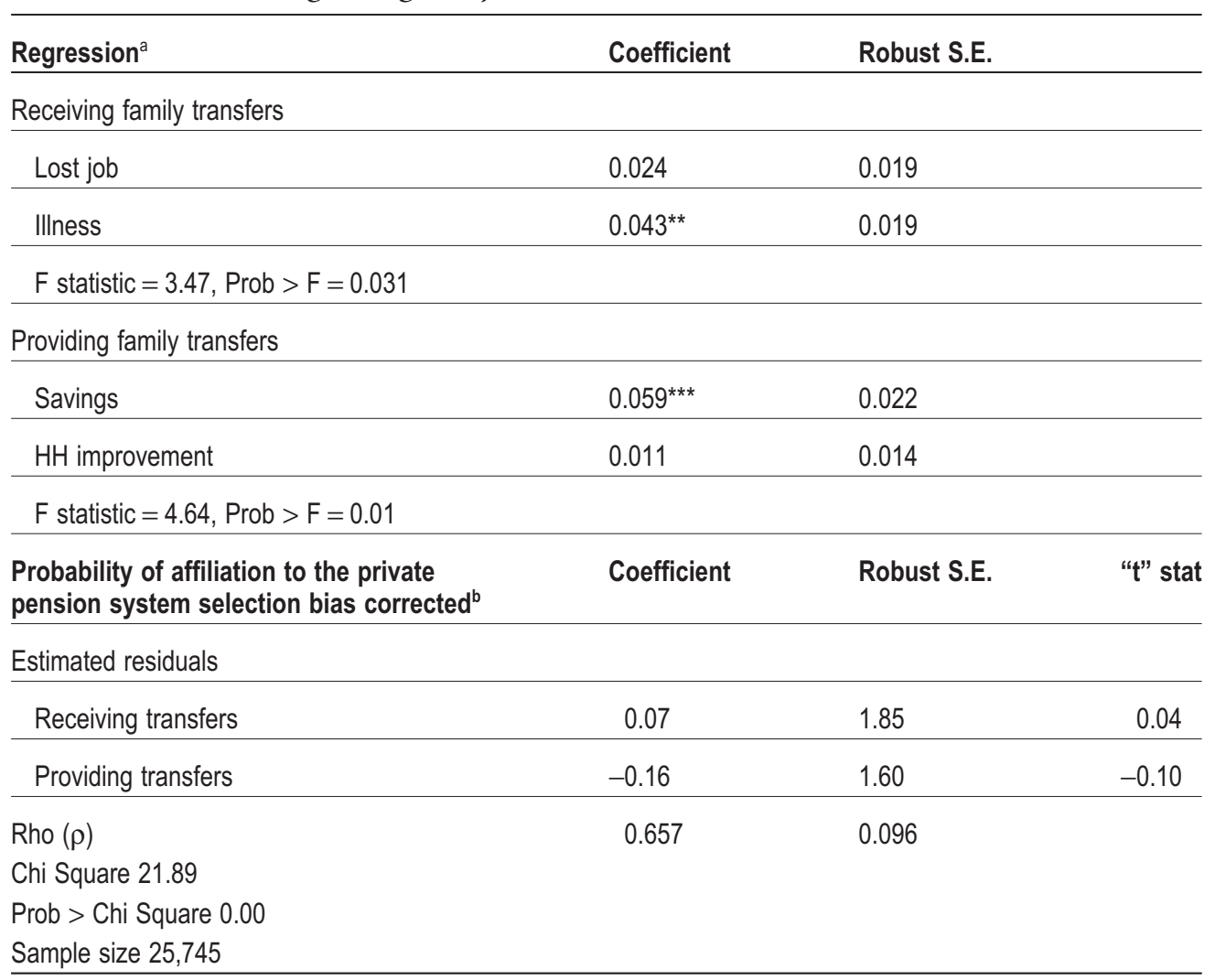

${ }^{a}$ The regression includes all variables form the original model except the variables instrumented. Standard error adjusted for intra-household correlation. F statistics to test joint significance of the instruments in each regression respectively. ${ }^{* * *}$ Sig. at 1 per cent, ${ }^{* *}$ Sig. at 5 per cent.

${ }^{b}$ The probit equation includes all variable from the original regression.

economic situation of the household; and 0 otherwise) and "HH improvement" (which takes the value of 1 if the individual has perceived an improvement in the living standard of the household with respect to the last year; and 0 otherwise).

Table 5 displays the results of the Rivers-Vuong endogenity test and provides evidence in favour of the null hypothesis that both receiving family transfers and providing family transfers are exogenous given the chosen instruments. Although one instrument in each of the possible endogenous variables had the expected sign but is statistically insignificant, the pair of chosen instruments is jointly significant at conventional levels. Note that we have assumed that the observations may be correlated within households, but would be independent between households. Allowing only for the conventional White-corrected standard errors, the estimated standard errors for all the instruments are smaller so the results are stronger. In any case, the estimated coefficients are exactly the same and the predicted residuals are statistically insignificant when included in the original probit equation. 
Table 6 presents our main results. Overall, the signs of the estimated coefficients are as expected. Age (and age squared) has a positive (negative) and a significant effect on the probability of affiliation. Our estimation suggests that for an individual with average characteristics, the probability of voluntary affiliation to the SPP peaks at age 54. This is not surprising once we calculate that the corresponding probability of voluntary affiliation is only 1 per cent. In other words, our result suggests that the probability of voluntary affiliation is indeed very low for the average working individual of any age. The education variables and variables related to household income have an important effect on the probability of voluntary affiliation and lend support to hypothesis 2 . In particular, holding a postgraduate degree increases the probability of affiliation by 2.2 per cent whilst holding a university degree does so by 1.4 per cent. High school education has the expected sign but is not statistically significant. Thus, the larger investment in human capital, the greater the chance of voluntary SPP affiliation. Individuals from households with both higher income per capita and in possession of liquid assets have a higher and significant probability of affiliation. The effect of household income per capita on the probability of affiliation is non-linear.

Married people have a positive and statistically significant larger probability of voluntary affiliation than singles. Gender by itself was found to be insignificant but the interaction gender ${ }^{\star}$ marital status exerted a negative influence on the affiliation probability. Married women might benefit from a widow's pension. Also they have more transient jobs and lower income mainly because of childbearing, so they have a lower probability of affiliation.

Although not statistically significant, the positive estimated coefficient of private health insurance suggests that it complements membership in a pension scheme. This can reflect wealth and/or proxy a higher degree of risk aversion.

The risk behaviour of other household members is also important in explaining SPP affiliation. We have found positive and statistically significant effects when any member of the household is affiliated to the SPP system and/or when they have life insurance. The effect of any member of the household receiving a pension is positive but statistically significant at the 10 per cent level. These results might be interpreted in several ways, one of them relates to "imitation" or "peer" effect: members of the household learn about the advantages of formal insurance schemes from other members already belonging to such schemes. Nevertheless, these results might also suggest that informal social security arrangements are not in place when various members of the household participate in formal social security.

With respect to hypothesis 3 , only household size is statistically significant and has the expected negative sign. However, we have to be cautious when interpreting family size. The number of household members might not be a good proxy for the extent of an informal social security safety net. Packard, Shinkai and Fuentes (2002) 
Table 6. Probability of affiliation to the SSP system (sample selection corrected)

\begin{tabular}{|c|c|c|c|}
\hline Variable & Coeff. & Robust S.E. & $\mathrm{dF} / \mathrm{dx}$ \\
\hline \multicolumn{4}{|l|}{ Individual characteristics } \\
\hline Woman & -0.012 & 0.100 & -0.0002 \\
\hline Married & $0.199^{* *}$ & 0.091 & 0.0033 \\
\hline Married*Woman & $-0.222^{*}$ & 0.127 & -0.0033 \\
\hline Age & $0.035^{\star * \star}$ & 0.011 & 0.0006 \\
\hline Age squared & $-3.2 \mathrm{E}-04^{* * *}$ & 0.000 & 0.0000 \\
\hline Head & 0.038 & 0.100 & 0.0007 \\
\hline Headfemale & 0.095 & 0.142 & 0.0018 \\
\hline Holding a private health insurance & 0.184 & 0.129 & 0.0031 \\
\hline Education & & 0.000 & 0.0000 \\
\hline Postgraduate & $0.603^{\star *}$ & 0.246 & 0.0219 \\
\hline University & $0.485^{* * *}$ & 0.092 & 0.0137 \\
\hline Vocational \& technical & $0.376^{* * *}$ & 0.097 & 0.0093 \\
\hline High school & 0.067 & 0.079 & 0.0011 \\
\hline \multicolumn{4}{|l|}{ Household characteristics } \\
\hline Household size & $-0.03^{* *}$ & 0.015 & -0.0005 \\
\hline Young dependants & $0.319^{\star *}$ & 0.163 & 0.0054 \\
\hline Old dependants & 0.022 & 0.164 & 0.0004 \\
\hline Extended family & 0.063 & 0.062 & 0.0011 \\
\hline Liquid asset gains & $0.244^{* *}$ & 0.100 & 0.0055 \\
\hline Receiving family transfers & $-0.136^{* *}$ & 0.058 & -0.0022 \\
\hline Providing family transfers & -0.016 & 0.059 & -0.0003 \\
\hline Receiving pensions & $0.237^{*}$ & 0.146 & 0.0054 \\
\hline Holding a life insurance & $0.405^{\star * *}$ & 0.094 & 0.0112 \\
\hline Other members in the SPP & $0.323^{* * *}$ & 0.069 & 0.0071 \\
\hline Log of household income per capita & $1.379^{* * *}$ & 0.502 & 0.0234 \\
\hline Log of household income p.c. squared & $-0.083^{* *}$ & 0.033 & -0.0014 \\
\hline Household is non poor & 0.075 & 0.083 & 0.0012 \\
\hline Urban zone & 0.033 & 0.088 & 0.0005 \\
\hline
\end{tabular}


Table 6. Continued

\begin{tabular}{|c|c|c|c|}
\hline Variable & Coeff. & Robust S.E. & $\mathrm{dF} / \mathrm{dx}$ \\
\hline Constant & $-9.029^{* * *}$ & 1.825 & \\
\hline Athrho & $0.787^{* * *}$ & 0.167 & \\
\hline Rho & 0.657 & 0.095 & \\
\hline \multicolumn{4}{|c|}{ Wald test of indep.eqns. $($ Rho $=0):$ chi2 $(1)=24.24$ Prob $>$ chi2 $=0.000$} \\
\hline Number of observations & 25,745 & & \\
\hline Uncensored observations & 21,677 & & \\
\hline Log pseudolikelihood & $-7,702$ & & \\
\hline chi2(26) & 304 & & \\
\hline Prob>chi2 & 0.00 & & \\
\hline
\end{tabular}

Dependent variable: Affiliated to SPP voluntary. Variables in selection equation: woman, married, age, education levels and informal. Standard error adjusted for intra-household correlation. ${ }^{* *}$ Significant at 1 per cent, ${ }^{* *}$ Significant at 5 per cent, * Significant at 10 per cent.

argue that larger households might have to share resources with more members and this effect might reduce the probability of SPP affiliation.

The percentage of young members in the household is statistically significant but has a positive sign. One possible explanation is that, by law, children younger than age 18 inherit a share of the pension, so a working parent (with many dependant children) who might run a higher risk of illness or death may be more likely to affiliate. ${ }^{19}$ In addition, older children (and older persons), by performing household chores, may exert a positive influence on the possibility of parental wage employment and, thus, affiliation to the pension system (Holzmann, Packard and Cuesta, 2000). It is to be noted that, in our regression, the percentage of family members aged 65 or older also has a positive sign but it is insignificant.

In terms of hypothesis 4, our results suggest a negative effect of the household receiving transfers and providing transfers on the probability of affiliation, but only the former is statistically significant. ${ }^{20}$ This might signal not only exchange-related issues between relatives but also that those receiving transfers are in more need than those providing them.

19. We ran the regression with the proportion of children younger than age 18 (instead of age 14). We report that the estimated coefficient remained positive but statistically significant only at 10 per cent. For a group of Latin American countries, Packard, Shinkai and Fuentes (2002) also found a positive influence of children and older persons on pension coverage.

20. Before including the dummy variables "receiving transfers" and "providing transfers", we tested the model with only one dummy variable which took the value of 1 if the household was "providing" or "receiving" transfers, and 0 otherwise. We found that this variable exerted a negative and significant effect on the probability of affiliation and that the estimated coefficients of the other regressors remain almost the same, so we decided not to report the results. 
Finally, we assess the extent of the bias introduced by not correcting for sample selection. The predicted probability of affiliation (calculated at mean values of the regressors) is 1.26 per cent without correction and 0.91 per cent with correction. More interesting, using the whole sample but without distinguishing between voluntary and mandatory affiliation, the predicted probability of affiliation is 7.5 per cent which is still very low but substantially higher than the one we have calculated.

\section{Conclusions}

We have examined the decision to participate in the individual accounts pension system (SPP) in Peru for individuals for whom the decision to affiliate is voluntary. Overall, our results support our hypotheses. Given the large informal sector in Peru, pension coverage is limited and restricted to a selected group of individuals. Among those with a choice of voluntary affiliation, married males with more than high school-level education who belong to households with higher income per capita and with other family members already affiliated to the SPP have the highest likelihood of using that choice. Moreover, our results also suggest that family-based safety nets have a negative effect on the probability of SPP affiliation. Family arrangements tend to substitute for formal social security membership but in the long run, taking into account the potential impacts of demographic ageing, we cannot be certain of the effectiveness of these.

Therefore, our results suggest that there is a risk of income insecurity in old age for many Peruvians: not only is the rate of affiliation low but rates of active contribution are also low. This is especially so among low-income informal workers. In 2001 coverage among employed workers of the two highest income quintiles was, on average, 18.8 times that of the two poorest quintiles (Rofman and Lucchetti, 2006) and, according to AIOS, the ratio of contributors to affiliates in the SPP was 41.9 per cent. Before discussing possible ways to address these challenges, it is important to bear in mind the objectives of a pension system based on individual accounts i.e. to transfer consumption from working to retirement age, allowing the old (and the disabled) to retire from work and live decently without outliving their pension savings. Market failures and additional objectives such as poverty relief and redistribution prompt government intervention (Barr and Diamond, 2006). One way to increase pension coverage is the creation of more "formal" jobs where pension coverage is mandatory. But this is a structural and long-term task, and the labourmarket trends in many countries in recent years have been in the opposite direction. As mentioned earlier, Peru's SPP system does not include a guaranteed minimum pension - rather, it provides a top-up amount to lift the pension income of eligible pensioners up to a guaranteed minimum — , so another possibility might be for the government to provide, as is the case in Chile, a means-tested "solidarity" pension for low-income persons of retirement age that have not participated in the pension 
scheme, in addition to a minimum top-up guarantee for people that have contributed to the system but have not been able to accumulate enough to achieve a minimum threshold pension. Besides issues of moral hazard and the provision of appropriate incentives, such a policy approach inevitably leads us to consider two distinct but interrelated problems: large fiscal costs and prioritizing the need to extend coverage.

Could policies, such as lowering the administrative fees charged by the AFPs help extend coverage? This might be so, but we found little association between commissions and contributions and voluntary pension affiliation. According to PRIESO, in order to make informed decisions about affiliating, individual information and knowledge about pension systems matter. And individual perceptions about institutional reputation and trust are equally important. It is recognized that the regulation of investments by pension funds and insurance companies should be carefully designed with the aim of safeguarding affiliates' contributions yet also providing sufficient flexibility to enable fund managers to follow optimal investment strategies. But, as a means to extend coverage, regulation might be less effective once household income is taken into account as a major factor in the probability of affiliating (and contributing) to the SPP pension scheme.

Although our results show a weak gender effect on the probability of SPP affiliation, Arenas de Mesa and Mesa-Lago (2006) find that the Chilean AFP system has accentuated gender inequality because women earn lower wages relative to men, have higher rates of unemployment, have interrupted work histories as a result of raising children and perform a larger share of the unskilled jobs for which there is no mandatory pension system coverage. Rofman and Grushka (2003) also found similar results for Argentina.

We concur with Arenas de Mesa and Mesa-Lago (2006) and Gill, Packard and Yermo (2005) that key issues not satisfactorily addressed by private individual accounts pension system reforms in Latin America, and Peru in particular, are those of coverage and compliance. We believe that in countries with a large self-employed low-income population, the issues regarding competition, efficiency and administrative costs of individual accounts are important but secondary. The debate about the fiscal sustainability and expansion of social assistance pensions to cover all the poor is controversial and complex. Although one country's pension system might not be suitable for another, an examination of the experiences of other countries might prove helpful. We leave these issues as well as the sustainability of informal family-based arrangements and the influence of labour market inequalities as matters for future research.

Finally, our findings must be taken with some caution due to data limitations. The cross section nature of our data does not allow us to capture the effects of changes of variables over time; in particular, the effect of supply-side variables (e.g. changes in fees for managing pension funds) on the probability of affiliation. Also, lack of savings data precludes us from examining the relation between savings and 
pension affiliation. In addition, we do not have a measure of intergenerational transfers but only data related to family transfers from and to other family members living outside the household. It would be desirable to have more detailed survey data to explore the effects of informal family safety nets on the decision to affiliate to the SPP system and also to have a history of contributions to be able to assess the extent of effective coverage and the problem of old-age vulnerability.

\section{Bibliography}

AIOS. 1999-2007. Boletín Estadístico AIOS (No. 1-18). International Association of Latin American Pension Fund Supervisors.

Arenas de Mesa, A.; Mesa-Lago, C. 2006. “The structural pension reform in Chile: Effects, comparisons with other Latin American reforms, and lessons", in Oxford Review of Economic Policy, Vol. 22, No. 1.

Arrondel, L.; Masson, A. 2006. “Altruism, exchange or indirect reciprocity: What do the data on family transfers show?" in S.C. Kolm and J. Mercier-Ytier (eds.), Handbook on the economics on giving, reciprocity and altruism. Amsterdam, Elsevier-North Holland.

Barr, A.; Packard, T. 2005. Seeking solutions to vulnerability in old age: Preferences, constraints, and substitutes for coverage under Peru's pension system (Working Paper, No. 2005-05). Oxford, Centre for the Study of African Economies.

Barr, N.; Diamond, P. 2006. "The economics of pensions", in Oxford Review of Economic Policy, Vol. 22, No. 1.

Bhaumik, S. K.; Nugent, J. 2000. "Wealth accumulation, fertility, and transfers to elderly household heads in Peru", in A. Mason and G. Tapinos (eds.), Sharing the wealth. Oxford, Oxford University Press.

Brown, J. R. 2001. "Private pensions, mortality risk, and the decision to annuitize", in Journal of Public Economics, Vol. 82, No. 1.

Carpio, M. 2007. Does pension saving crowd out voluntary saving? Evidence from social security privatization in Peru (Unpublished). Barcelona, Universitat Pompeu Fabra.

Cigno, A. 2000. "Saving, fertility and social security in the presence of self-enforcing intrafamily deals", in A. Mason and G. Tapinos (eds.), Sharing the wealth. Oxford, Oxford University Press.

Cox, A.; Edwards, S. 2002. "Social security privatization reform and labor markets: The case of Chile", in Economic Development and Cultural Change, Vol. 50, No. 3.

Cox, D.; Eser, Z.; Jimenez, E. 1998. "Motives for private transfers over the life-cycle: An analytical framework and evidence for Peru", in Journal of Development Economics, Vol. 55, No. 1.

Cox, D.; Rank, M. 1992. "Inter-vivos transfers and intergenerational exchange", in Review of Economics and Statistics, Vol. 74, No. 2.

Cruz-Saco, M. A.; Mesa-Lago, C. 1998. Do options exist? The reform of pension and health care systems in Latin America. Pittsburgh, PA, University of Pittsburgh Press. 
Gill, I., Packard, T.; Yermo, J. 2005. Keeping the promise of social security in Latin America. Washington, DC, World Bank.

Hausman, J. 2001. "Mismeasured variables in econometric analysis: Problems from the right and problems from the left", in Journal of Economic Perspectives, Vol. 15, No. 4.

Hausman, J.; Abrevaya, J.; Scott-Morton, F. M. 1998. "Misclassification of the dependent variable in a discrete-response setting", in Journal of Econometrics, Vol. 87, No. 2.

Heckman, J. J. 1979. “Sample selection bias as specification error”, in Econometrica, Vol. 47, No. 1.

Hoddinott, J. 1992. "Rotten kids or manipulative parents: Are children old age security in western Kenya?" in Economic Development and Cultural Change, Vol. 40, No. 3.

Holzmann, R. 1997. "Pension reform, financial market development, and economic growth: Preliminary evidence from Chile", in IMF Staff Papers, Vol. 44, No. 2.

Holzmann, R.; Packard, T.; Cuesta, J. 2000. Extending coverage in multi-pillar pension systems: Constraints and hypotheses, preliminary evidence and future research agenda (Social Protection Discussion Paper Series, No. 0002). Washington, DC, World Bank.

ILO. 2008. 2007 Labour overview: Latin America and the Caribbean. Lima, International Labour Organization - Regional Office for Latin America and the Caribbean. <http:// www.oit.org.pe/WDMS/bib/publ/panorama/labour_overview_07.pdf> (accessed on 02.04.2009).

INEI. 2001. Censos nacionales. Lima, National Institute of Statistics and Informatics.

Jellal, M.; Wolff, F. C. 2002. "Insecure old-age security", in Oxford Economic Papers, Vol. 54, No. 4.

Jimenez, L.; Cuadros, J. 2003 "Expanding the coverage of pension systems in Latin America”, in CEPAL Review, No. 79.

Kotlikoff, L.; Spivak, A. 1981. "The family as an incomplete annuities market”, in Journal of Political Economy, Vol. 89, No. 2.

Laferrere, A.; Wolff, F. C. 2006. "Microeconomic models of family transfers", in S.C. Kolm and J. Mercier-Ytier (eds.), Handbook on the economics on giving, reciprocity and altruism. Amsterdam, Elsevier-North Holland.

Li, C. A.; Gerry, C. 2009. "Consumption smoothing and vulnerability in Russia", in Applied Economics, forthcoming.

Lucas, R. T.; Stark, O. 1985. "Motivations to remit: Evidence from Botswana”, in Journal of Political Economy, Vol. 93, No. 5.

Mesa-Lago, C. 2004. "An appraisal of a quarter-century of structural pension reforms in Latin America", in CEPAL Review, No. 84.

Morón, E.; Carranza, E. 2003. Diez años del sistema privado de pensiones: Avances, retos y reformas 1993-2003. Lima, Universidad del Pacífico - Centro de Investigación.

Packard, T.; Shinkai, N.; Fuentes, R. 2002. The reach of social security in Latin America and the Caribbean (Background paper for Regional Study on Social Security Reform). Washington, DC, World Bank - Office of the Chief Economist for the Latin America \& the Caribbean. 
Public Pension Standardization Office. various years. Estadísticas ONP. Lima.

Public Pension Standardization Office. 2000-2007. ONP's summary of Annual economic study of pension reserves. Lima.

Queisser, M. 1998. The second generation pension reforms in Latin America. Paris, OECD Development Centre.

Rofman, R. 2005. Social security coverage in Latin America (Social Protection Discussion Paper, No. 0523). Washington, DC, World Bank.

Rofman, R.; Grushka, C. 2003. "Protección social, jubilaciones y pensiones y género en Argentina", in F. Bertranou and A. Arenas de Mesa (eds.), Protección social y género en Argentina, Brasil y Chile. Santiago de Chile, International Labour Organization Subregional Office for the South Cone of Latin America. <http://www.oitchile.cl/pdf/ publicaciones/pro/pro011.pdf> (accessed on 09.03.2009).

Rofman, R.; Lucchetti, L. 2006. Pension systems in Latin America: Concepts and measurement of coverage (Social Protection Discussion Paper, No. 0616). Washington, DC, World Bank.

Rivers, D.; Vuong, Q. H. 1988. "Limited information estimators and exogeneity tests for simultaneous probit models", in Journal of Econometrics, Vol. 39, No. 3.

Schmidt-Hebbel, K. 1999. Latin America's pension revolution: A review of approaches and experience. (Conference paper, World Bank's ABCDE Conference, April 28-30, Washington, DC). Central Bank of Chile. <http://siteresources.worldbank.org/ INTABCDEWASHINGTON1999/Resources/hebbel.pdf> (accessed on 09.03.2009).

Stark, O. 1995. Altruism and beyond: An economic analysis of transfers and exchanges within families and groups. Cambridge, Cambridge University Press.

Superintendency of Banks and Insurance of Peru. various years. Boletín informativo mensual. Lima. <http://www.sbs.gob.pe/portalSBS/estadistica/index.htm> (accessed on 02.04.2009).

Superintendency of Banks and Insurance of Peru. various years. Series históricas. Lima. $<$ http://www.sbs.gob.pe/portalSBS/estadistica/index.htm> (accessed on 02.04.2009).

Uthoff, A. 2001. La reforma del sistema de pensiones en Chile: Desafíos pendientes (Serie Financiamiento del Desarrollo, No. 112). Santiago, CEPAL. <http://www.eclac. org/publicaciones/xml/7/7367/lcl1575e.pdf> (accessed on 02.04.2009).

Victorio, A. 2002. "Non-market insurance and intrafamily transfers", in Applied Economics Letters, Vol. 9, No. 2.

Wooldridge, J. 2002. Econometric analysis of cross section and panel data. Cambridge, MA, MIT Press. 